\title{
Spontaneous Bleeding in a Patient with Malignant Lymphoma: A Case of Acquired Hemophilia
}

\author{
W. Gesierich R. Munker U. Geiersberger H. Pohlmann N. Brack R. Hartenstein \\ IV. Medizinische Abteilung des Städtischen Krankenhauses München-Harlaching \\ Akademisches Lehrkrankenhaus der Ludwig-Maximilians-Universität München
}

\section{Key Words}

Factor VIII inhibitor · Non-Hodgkin's Iymphoma · Immunosuppressive therapy

\section{Summary}

Background: Acquired hemophilia is a rare condition which can be associated with lymphoproliferative disease. Case Report: Eleven years after the diagnosis of immunocytoma had been made, a 72-year-old man developed a high-titer factor VIII inhibitor. At this time, the lymphoma was without significant progress and there was no paraprotein in the serum. Partial thromboplastin time (PTT) was $83 \mathrm{~s}$, factor-VIII clotting activity was $<1 \%$, and inhibitor level was 50.4 Bethesda units. The patient presented with spontaneous hematomas in the skin and musculature of the extremities. Following combination chemotherapy with cyclophosphamide, vincristine and prednisolone (COP), there was a prompt disappearance of the inhibitor and normalization of coagulation; however, the patient developed serious infectious complications. When the inhibitor recurred he was treated with low-dose cyclophosphamide and prednisolone. This time there was a more delayed response, but the inhibitor disappeared again completely. Two months after cessation of therapy, there was again relapse. Conclusion: Causal relationship between lymphoma and acquired hemophilia remains speculative. At least in some cases of factor VIII inhibitors associated with malignant disease, immunosuppressive therapy may be sufficient to suppress the inhibitor.

\section{Introduction}

A cquired hemophilia due to factor VIII inhibitor is a rare clinical condition. The incidence is reported as about one per million annually [1, 2]. B ut it represents the most common type of spontaneously acquired inhibitors against a clotting factor

\section{Schlüsselwörter}

Faktor-VIII-Inhibitor · Non-Hodgkin-Lymphom · ImmunsuppressiveTherapie

\section{Zusammenfassung}

Hintergnund: Die erworbene Hämophilie ist selten und kann mit lymphoproliferativen Erkrankungen assoziiert sein. Kasuistik: Elf J ahre nach Diagnosestellung eines Immunozytoms entwickelte ein 72jähriger Mann einen hochtitrigen Faktor-VIII-Inhibitor. Zu dieser Zeit zeigte das Lymphom keinen eindeutigen Progreß und im Serum war kein Paraprotein nachweisbar. Die partielleThromboplastinzeit (PTT) betrug 83s, Faktor VIII: C war $<1 \%$ und der Inhibitor-Titer lag bei 50,4 Bethesda-Einheiten. Der Patient entwickelte spontane Hämatome an Haut und Muskulatur der Extremitäten. Nach Polychemotherapie mit Cyclophosphamid, Vincristin und Prednisolon (COP) kam es zu einem raschen Verschwinden des Inhibitors und zu einer Normalisierung der Gerinnung, der Patient entwickelte jedoch schwere Infektkomplikationen. Ein Rezidiv wurde mit niedrig dosiertem Cyclophosphamid und Prednisolon behandelt. Das Ansprechen schien protrahiert, aber der Inhibitor verschwand wieder vollständig. Zwei Monate nach Therapiebeendigung zeichnete sich ein neues Rezidiv ab. Schlußfolgenung: Ob ein Kausalzusammenhang zwischen dem Lymphom und der erworbenen Hämophilie besteht, kann nur spekuliert werden. Zumindest in einigen Fällen von Faktor-VIII-Antikörpern, die mit malignen Erkrankungen assoziiert sind, kann eine immunsuppressive Therapie ausreichen, um den Inhibitor zu unterdrücken.

[3]. Both sexes are affected equally $[1,4]$. The incidence increases with age, the majority of patients being over 50 years of age. There is a second small peak of incidence in the 3rd decade, accounted for by women affected around parturition [4]. A wide range of associated conditions has been described in the literature. In a large survey [4] of 215 patients with factor

\begin{tabular}{ll}
\hline KARGER & ○ 2000 S. Karger G mbH, Freiburg \\
$\begin{array}{l}\text { Fax +49 761 4520714 } \\
\begin{array}{l}\text { E-mail Information@K arger.de } \\
\text { www.karger.com }\end{array}\end{array}$ & $\begin{array}{l}\text { A ccessible online at: } \\
\text { www.karger.com/journals/onk }\end{array}$ \\
\end{tabular}

Dr. med. Wolfgang Gesierich

IV. M edizinische A bteilung des Städtischen K rankenhauses M ünchen-H arlaching A kademisches L ehrkrankenhaus der L udwig-M aximilians-U niversität M ünchen Sanatoriumsplatz 2, D-81545 M ünchen (G ermany) 
VIII inhibitors, $18 \%$ had concomitant autoimmune disorders like rheumatoid arthritis and systemic lupus erythematosus, $7 \%$ were postpartum women, $7 \%$ had malignancies, $5 \%$ had been trated with drugs (penicillin, phenytoin), $5 \%$ had skin disorders like psoriasis and pemphigus, and $12 \%$ had various conditions like asthma, multiple transfusions, diabetes or hepatitis. In $46 \%$, no associated disease could be identified. Beside this case series, both various solid tumors $[5,6]$ and hematologic malignancies [3, 7-14] like plasma cell dyscrasias and lymphoproliferative disease are reported frequently in the literature in conjunction with factor VIII inhibitors. Whereas in autoimmune disorders and hematologic malignancies a causal relation between autoantibody formation and associated disease seems possible, as there is both a plausible pathogenesis and clinical evidence $[3,15]$, the nature of this correlation is less clear for most of the other conditions. A nd the fact that most of them tend to occur in the elderly may indicate a coincidental relationship [1].

\section{Case Report}

A 72-year-old man was admitted to the hospital because of spontaneous hematomas of the upper and lower extremities. E leven years before admission, the diagnosis of a low-grade non-H odgkin's lymphoma, specified as nonsecretory immunocytoma stage IV A ( $B$ inet stage $A$ ) with enlargement of axillary, supraclavicular, mediastinal and paraaortal lymph nodes and infiltration of bone marrow, had been made. The patient had no treatment, and during regular follow-up no progression of the lymphoma was observed. He had developed anteroseptal myocardial infarction 21 years before admission and since then suffered from stable angina pectoris, which was controlled by bisoprolol and isosorbide dinitrate. In addition he took acetylsalicylic acid 100 mg daily. He had a history of psoriasis, which was without any activity at admission. He had scmoked until 11 years before admission.

Three weeks before admission he consecutively developed hematomas of the left elbow, right upper arm, left thigh, right gluteal region and left forearm, which had led to tension of the musculature with imminent compartment syndrome. A II hematomas developed overnight without adequate trauma. The patient's general practitioner found a prolonged partial thromboplastin time (PTT), which until then had been normal in all routine controls. Intravenous injection of vitamin $\mathrm{K} 2$ days before admission had been without effect on PTT. O $n$ admission, the patient was well except for a mild exertional dyspnea. The musculature of the left forearm was tense and tender, but radial pulses were palpable on either side. No petechial bleeding could be found. There was no past or family history of bleeding tendency. The temperature was $37^{\circ} \mathrm{C}$, the pulse was $76 / \mathrm{min}$, and blood pressure was 120/70 $\mathrm{mm} \mathrm{H} \mathrm{g.} \mathrm{O} \mathrm{n} \mathrm{auscultation,} \mathrm{lung} \mathrm{and} \mathrm{heart} \mathrm{sounds}$ were clear. The abdomen was soft without evidence of ascites or organomegaly. Small lymph nodes could be palpated in both axillae and the right supraclavicular region. The bleeding time, measured with the standardized Surgicutt device, was normal (4 min). The urine was positive $(+++)$ for blood. L aboratory tests were performed (table 1). The electrocardiogram was without pathologic finding. A chest radiograph showed slight left ventricular enlargement and pleural adhesions at the base of the right lung, which was known from previous films.

Two units of fresh frozen plasma were given on the 1st hospital day and were without effect on the PTT. Oral antibiotic treatment with cefaclor was initiated to prevent superinfection of hematomas. The left forearm was cooled with ice to prevent further swelling and compartment syndrome. While microscopical examination of a blood smear was normal, immunophenotyping of the peripheral blood by flow cytometry showed elevation of CD 19+ B cells (69\% of mononuclear cells CD 19+; $21 \%$ CD 3+) and light-chain restriction in CD 19+ B cells (47\% $\left.C_{k} / C D 19+; 1 \% \quad C_{\lambda} / C D 19+\right)$,
Table $1 . L$ aboratory values on first admission

\begin{tabular}{|c|c|c|}
\hline & $\begin{array}{l}\text { Patient } \\
\text { value }\end{array}$ & $\begin{array}{l}\text { Normal } \\
\text { value }\end{array}$ \\
\hline White cell count/nl & 12.1 & $4.0-10.0$ \\
\hline \multicolumn{3}{|l|}{ D ifferential count } \\
\hline Neutrophils, \% & 42 & $50-70$ \\
\hline Lymphocytes, \% & 47 & $25-40$ \\
\hline M onocytes, \% & 5 & $2-10$ \\
\hline E osinophils, \% & 2 & $0-5$ \\
\hline B asophils, \% & 1 & $0-1$ \\
\hline H emoglobin, g/dl & 11.7 & $14.0-18.0$ \\
\hline Platelet count/nl & 168 & $150-400$ \\
\hline INR & 0.9 & \\
\hline PTT, s & 83 & $26-36$ \\
\hline Creatine, mg/dl & 1.2 & $0.7-1.2$ \\
\hline Sodium, mmol/l & 142 & $135-145$ \\
\hline Potassium, mmol/l & 3.9 & $3.5-5.0$ \\
\hline Total protein, g/dl & 6.9 & $6.1-8.2$ \\
\hline \multicolumn{3}{|l|}{ Serum electrophoresis } \\
\hline A lbumin, $\%$ & 66.1 & $55.0-69.0$ \\
\hline$\alpha 1-G$ lobulin, $\%$ & 4.1 & $1.6-5.8$ \\
\hline$\alpha 2-G$ lobulin, $\%$ & 7.8 & $5.9-11.1$ \\
\hline$\beta-G$ lobulin, $\%$ & 13.0 & $8.0-12.0$ \\
\hline$\gamma$-G lobulin, $\%$ & $9.0^{\mathrm{a}}$ & $11.0-20.0$ \\
\hline C-reactive protein, $\mathrm{mg} / \mathrm{dl}$ & 0.7 & $0.0-0.8$ \\
\hline$\beta 2-\mathrm{M}$ icroglobulin, mg/l & 1.8 & $0.8-2.5$ \\
\hline \multicolumn{3}{|l|}{ Immunoglobulin } \\
\hline $\mathrm{G}, \mathrm{mg} / \mathrm{l}$ & 507 & $700-1,600$ \\
\hline $\mathrm{A}, \mathrm{mg} / \mathrm{l}$ & 60 & $70-400$ \\
\hline $\mathrm{M}, \mathrm{mg} / \mathrm{l}$ & 90 & $40-230$ \\
\hline Thyroid-stimulating hormone, mE / & 1.6 & $0.2-3.5$ \\
\hline Cardiolipin antibodies, G PL -U/ml & 2 & $0-12$ \\
\hline
\end{tabular}

${ }^{a}$ Without monoclonal component.

consistent with the presence of a malignant clone of $B$ cells in the peripheral blood. A $n$ abdominal ultrasound scan showed multiple concrements in the gallbladder. A CT scan of the abdomen showed multiple paraaortic and paracaval lymph nodes enlarged slightly above $1 \mathrm{~cm}$. A CT scan of the thorax showed multiple mediastinal lymph nodes also at the size of $1 \mathrm{~cm}$. On the 6th hospital day, factor V III clotting activity (factor V III:C) was lower than 1\% (normal range 70-150\%) and could not be raised substantially immediately and $2 \mathrm{~h}$ after mixing of patient and normal plasma, indicating the presence of a factor VIII inhibitor in the patient plasma. The inhibitor level was determined with 50.4 Bethesda units. PTT and factor VIII:C did not change substantially 2, 4, and $10 \mathrm{~h}$ after intravenous infusion of desmopressin acetate (36 $\mu \mathrm{g}$ in $30 \mathrm{~min}$ ). The von Willebrand factor activity was $152 \%$. The diagnosis of acquired hemophilia caused by factor VIII inhibitor possibly related to low-grade non-H odgkin's lymphoma (immunocytoma) was made.

On the 8th hospital day, immunosuppressive therapy with steroids (prednisolone $100 \mathrm{mg} /$ day) was initiated and chlorambucil ( $20 \mathrm{mg}$ on day 8 and $15 \mathrm{mg}$ on day 9) was given to treat the underlying malignant disease. To prevent further and probably life-threatening bleeding, 3,000 IU of activated prothrombin complex concentrate with factor VIII inhibitor bypassing activity (FEIBA S-TIM 4 Immuno ${ }^{\circledR}$, B axter, Vienna, A ustria) were given intravenously as a bolus on days 10-14. A s only a slight decrease of PTT could be achieved by these measures, the need for a more intensive antineoplastic therapy was seen. On the 12th hospital day, polychemotherapy was initiated according to the COP regimen (cyclophosphamide $400 \mathrm{mg} / \mathrm{m}^{2}$ i. v., days 1-5; vincristine $2 \mathrm{mg}$ i. v., day 1; prednisolone $100 \mathrm{mg}$ 


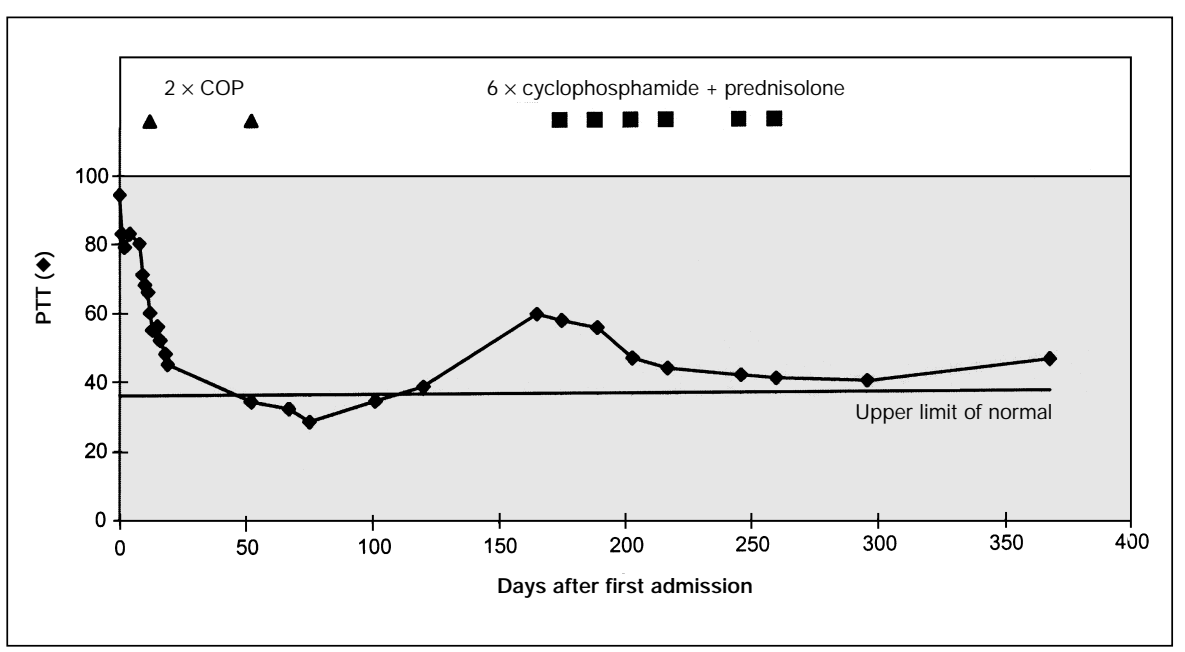

Fig. 1 PTT and chemotherapy.

per os days 1-5). Consecutively, PTT dropped to $45 \mathrm{~s}$ on the 20th hospital day without clinical signs of further bleeding, and the patient could be discharged. Steroid therapy was continued with prednisolone $100 \mathrm{mg} /$ day. On day 52 after first admission, the patient presented without any further bleeding and with a normal PTT. Prednisolone was reduced to $50 \mathrm{mg} /$ day The second course of COP chemotherapy was given in an outpatient setting in our hematologic clinic. $0 \mathrm{n}$ day 67 , the patient was admitted to the hispital with bilateral atypical pneumonia and exanthema of the right inguinal region and scrotum which was suspicious for herpes simplex. White blood count was 1.1/nl. Prednisolone was tapered, $30 \mathrm{~g}$ immunoglobulins and broad-spectrum antimicrobial therapy were given intravenously. N eutropenia resolved on the 2 nd day, but the clinical condition improved slowly. O n day 101, factor VIII:C was $57.0 \%$, consistent with lowtiter factor V III inhibitor. On bone marrow aspiration, a focal infiltration by lymphocytes $(5 \%)$ showing morphologic characteristics of immunocytes was found. Immunophenotyping of bone marrow blood confirmed light-chain restriction in CD $19+$ lymphocytes $\left(15 \% \quad C_{k} / C D 19+;<1 \%\right.$ $\left.C_{\lambda} / C D 19+\right)$, consistent with infiltration of the bone marrow by the malignant $\mathrm{B}$-cell clone. A s there was no further bleeding, a decision for a waitand-see strategy was made.

Consecutively, PTT slowly increased and exceeded the upper limit of normal on day 120, but factor VIII:C was $85 \%$ and the patient was well without bleeding.

On day 165, PTT was $59 \mathrm{~s}$, factor VIII:C had decreased to $2 \%$ and factor VIII inhibitor level was 1.6 B ethesda units. A Ithough there was no bleeding, the need for therapy was seen. Regarding the severe infectious complications of polychemotherapy and the lack of significant lymphoma progression, a decision was made for a mild nonmyelotoxic immunosuppressive therapy with cyclophosphamide $100 \mathrm{mg}$ per os, days 1-4, and prednisolone $100 \mathrm{mg}$ per $0 \mathrm{~s}$, days 1-4, q15 days. Six courses of this therapy were given starting on days $175,189,203,217,246$, and 260 . D uring this period, PTT slowly decreased without reaching normal range, factor VIII:C rose to $65 \%$ on day 246 with undetectable factor VIII inhibitor, and no bleeding, neutropenia, or infectious complications developed. On reevaluation on day 368 , the PTT showed a tendency to increase (45 s), indicating recurrence of factor VIII inhibitor (fig. 1).

\section{Discussion}

Factor VIII inhibitors bind to functional epitopes or antigeneic sites of the factor VIII molecule, preventing interaction with other clotting factors or increasing neutralization [17]. The development of a factor VIII inhibitor has serious conse- quences. In a large survey [4], major bleeding occurred in $87 \%$ of patients, and $22 \%$ died either directly or indirectly as a consequence of having the inhibitor. The most common presentation is bleeding into the skin, soft tissue and muscles, which can lead to compartment syndrome. There can be mucosal bleeding like epistaxis, gastrointestinal bleeding or hematuria. In elderly patients with concomitant cardiac disease the resulting anemia may lead to angina pectoris or signs of heart failure. There may be iatrogenic bleeding after invasive diagnostic procedures, intravenous catheter placement and surgery [1]. Retroperitoneal and intraperitoneal hemorrhage is often fatal $[4,16]$. For unknown reasons, joint bleeding seems to be rare in contrast to congenital hemophilia [2].

The hallmark of laboratory diagnosis of factor VIII inhibitors is prolongation of the PTT, whereas the prothrombin time is normal. Factor VIII:C is measured in a mixing assay using factor VIII-deficient plasma. Mixing of normal and patient plasma can distinguish between primary factor deficiency (like in congenital hemophilia and von Willebrand's disease) and secondary deficiency due to an inhibitor. While addition of normal plasma to factor-deficient plasma normalizes the PTT, mixing of normal plasma with plasma containing an inhibitor fails to correct PTT. A widely accepted method for quantifying the inhibitor is the Bethesda assay $[17,18]$. D ilutions of patient plasma are incubated with normal pooled plasma for $2 \mathrm{~h}$ at $37^{\circ} \mathrm{C}$, and residual F VIII:C is measured and expressed as percentage of a control assay. R esults are converted to antibody units using a conversion graph and multiplying according to the dilutions used. One Bethesda unit (BU) represents the amount of antibody that yields $50 \%$ residual activity in the test system. Quantification of the inhibitor may be an important prerequisite for treatment decisions [1].

$M$ anagement of patients with factor VIII inhibitors has two objectives: (1) therapy and prevention of acute bleeding, and (2) reduction and elimination of the autoantibody [1].

The therapy of acute bleeding requires a variety of expensive blood products dependent on the titer of inhibitor (table 2). In patients with a low-titer inhibitor, elevation of factor VIII level with desmopressin (DDAVP) or substitution of human factor VIII may be sufficient. In patients with higher titers the substi- 
Table 2. Treatment of acute bleeding

\begin{tabular}{|c|c|c|}
\hline $\begin{array}{l}\text { Titer, } \\
\text { BU }\end{array}$ & Bleeding & Treatment \\
\hline$<5$ & $\begin{array}{l}\text { not limb- or } \\
\text { life-threatening }\end{array}$ & $\begin{array}{l}\text { a) DDAVP, } 0.3 \mu \mathrm{g} / \mathrm{kg} \text { i.v. over } 20 \mathrm{~min} \text {. If no response, give } \\
\text { b) R ecombinant human F VIII, } 100 \mathrm{U} / \mathrm{kg} \text {, then } 10 \mathrm{U} / \mathrm{kg} / \mathrm{h} \text {, or } \\
\text { c) Porcine F VIII, 0-100 U/kg, then } 4 \mathrm{U} / \mathrm{kg} / \mathrm{h}\end{array}$ \\
\hline $5-30$ & serious & $\begin{array}{l}\text { a) Porcine F VIII, 50- } 100 \mathrm{U} / \mathrm{kg} \text {, then } 4 \mathrm{U} / \mathrm{kg} / \mathrm{h} \text {, or } \\
\text { b) Recombinant human } \mathrm{F} V \mathrm{II} \text {, } 90 \mu \mathrm{g} / \mathrm{kg} \text { every } 2-3 \mathrm{~h} \text {, or } \\
\text { c) A ctivated prothrombin complex concentrate, } 50-75 \mathrm{U} / \mathrm{kg} \text { every } 8-12 \mathrm{~h}\end{array}$ \\
\hline$>30$ & serious & $\begin{array}{l}\text { a) Porcine F VIII, 100-200 U / kg, then } 10 \mathrm{U} / \mathrm{kg} / \mathrm{h} \text {, or } \\
\text { b) R ecombinant human F V IIa, } 90 \mu \mathrm{g} / \mathrm{kg} \text { every } 2-3 \mathrm{~h} \text {, or } \\
\text { c) A ctivated prothrombin complex concentrate, } 50-100 \mathrm{U} / \mathrm{kg} \text { every } 8-12 \mathrm{~h}\end{array}$ \\
\hline
\end{tabular}

tution of porcine factor V III, which interacts less strongly with autoantibodies and thus leads to higher levels of circulating, F VIII:C $[19,20]$, may be indicated. A Iternatives are the use of recombinant factor VIIa [21], which activates factor $X$ when complexed with tissue factor at the site of injury, thus bypassing deficient factor VIII and resulting in local thrombin formation; or of activated prothrombin complex preparation, which likewise bypass factor VIII. Factor substitution can be preceded by plasmapheresis or immunoadsorption if available. A nother method to decrease the inhibitor level in the phase of acute bleeding is the intravenous infusion of high-dose immunoglobulins (e. g., $1 \mathrm{~g} / \mathrm{kg}$ daily for 2 days), as these preparations contain anti-idiotypic antibodies, which are directed against the patient's autoantibody [22].

It is still under debate whether the factor VIII inhibitor can be reduced and possibly eliminated by immunosuppressive therapy with steroids and/or cytotoxic drugs. A pproximately on third of patients who receive supportive therapy only (transfusion of blood and factor concentrates) show spontaneous remission. These are mostly patients in pregnancy and postpartum or without underlying disease and low-titer inhibitors, who rarely develop life-threatening bleeding $[2,4]$. Following this observation, some authors tend to regard acquired hemophilia as a rather benign condition not warranting, some authors tend to regard acquired hemophilia as a rather benign condition not warranting the use of potent immunosuppressive and possibly oncogenic drugs. However, spontaneous loss of the antibody is unpredictable, may take months or years during which the patient is at risk for serious hemorrhage, and supportive therapy with blood products is expensive. Therefore, efforts to reduce or eliminate the antibody are justified. A large survey [4] showed that $56 \%$ of patients had benefit from drug therapy (either steroids or cytotoxic drugs or both), suggesting that immunosuppressive therapy accelerates inhibitor disappearance compared with supportive therapy alone. There is much anecdotal evidence for the efficacy of immunosuppressive therapy $[3,5,8-10,23]$. A prospective randomized trial [16, 24] showed the efficacy of prednisone and cyclophosphamide both alone and in combination. I $n$ this trial, responders to drug therapy had lower mean factor VIII antibody titers and higher mean factor VIII levels compared to non responders.
B ased on this evidence, it is recommended [1] to administer steroids as a 1st-line treatment (prednisolone $1 \mathrm{mg} / \mathrm{kg}$ for 3 weeks, then taper). If the inhibitor persists, cytotoxic drugs like cyclophosphamide ( $2 \mathrm{mg} / \mathrm{kg}$ orally for 3-6 weeks) or azathioprine ( $2 \mathrm{mg} / \mathrm{kg} / \mathrm{day}$ orally) should be given as $2 \mathrm{nd}$-line treatment either alone, in combination with steroids, or in combination chemotherapy like the COP regimen. Should antibodies persist, cyclosporine is another option of proven efficacy for the 3rd-line therapy (up to $5 \mathrm{mg} / \mathrm{kg} /$ day yielding plasma levels of $150-350 \mathrm{ng} / \mathrm{ml}$ ). Therapy should be continued until complete normalization of coagulation, and retreatment may be needed if inhibitors recur [23].

In our case there are two disorders, which are regarded as possibly connected to factor VIII antibody formation: (1) psoriasis, which was without significant activity at the point of antibody appearance and during all follow-ups, and (2) lowgrade B-cell lymphoma, which had been diagnosed 11 years prior to the appearance of factor VIII antibodies and had been without significant progress apart from the development of an immunoglobulin deficiency. Furthermore, there was no monoclonal gammopathy, to which the activity against factor VIII could have been ascribed. A ntibodies against factor V III are known to be predominantly composed of immunoglobulin G [18]. In a case of Waldenström's disease, factor V III antibodies have been shown to be polyclonal IgG molecules and thus not to be part of the IgM paraprotein [14].

In our case, it can only be speculated about the nature of the relationship between factor VIII antibodies and lymphoma. A utoantibodies can arise from malignant $B$ cells or from a normal polyclonal lymphatic population. Autoantibody formation in normal lymphocytes can be triggered by the presence of a malignant cell clone. A Iternatively, both disorders only coincidentally coexist in one individual.

With the intention to treat 'underlying' disease the patient received two courses of COP polychemotherapy with prompt normalization of coagulation parameters but with serious infectious complications. A t recurrence of the inhibitors he received immunosuppressive therapy with prednisolone and cyclophosphamide with a more delayed response. B oth therapies were effective but neither completely eradicated the inhibitor. U nder either therapy the Iymphoma showed no significant 
change. We conclude that, at least in some cases of factor V III inhibitors associated with malignancy, immunosuppressive therapy may be sufficient to suppress the inhibitor, and antineoplastic chemotherapy is not warranted unless indicated by the course of malignant disease itself.

\section{Acknowledgement}

We are indebted to Professor Schramm, A bteilung für $\mathrm{H}$ ämostaseologie, L udwig-M aximilians-U niversität $M$ ünchen, $K$ linikum Innenstadt, for measurement of factor VIII:C and inhibitor levels.

\section{References}

1 Feinstein D, G reen D, Federici A, G oodnight S: Diagnosis and management of patients with spontaneous acquired inhibitors of coagulation; in Hematology 1999. A merican Society of Hematology Education Program B ook, L ouisiana 1999, pp 192-208.

$2 \mathrm{~L}$ ottenberg $\mathrm{L}, \mathrm{K}$ entro $\mathrm{K}, \mathrm{K}$ itchens $\mathrm{C}$ : A cquired hemophilia. A natural history study of 16 patients with factor VIII inhibitors receiving little or no therapy. A rch Intern Med 1987;147:1077-1081.

$3 \mathrm{H}$ ultin $\mathrm{B}$ : A cquired inhibitors in malignant and nonmalignant disease states. A m J M ed 1991;91:5A -9S.

$4 \mathrm{G}$ reen $\mathrm{D}$, L echner $\mathrm{K}: \mathrm{A}$ survey of 215 non-hemophilic patients with inhibitors to factor VIII. Tromb H aemost 1981;45:200-203.

$5 \mathrm{H}$ auser I, Lechner K: Solid tumors and factor VIII antibodies. Thromb H aemost 1999;82:1005-1007.

6 Sallah S, Singh P, Hanrahan L: A ntibodies against factor VIII in patients with solid tumors: Successful treatment of cancer may suppress inhibitor formation. $\mathrm{H}$ aemostasis 1998;28:244-249.

7 Wanddell C, Lehane D, Zubler M : A cquired factor VIII inhibitor in a patient with mycosis fungoides Cancer 1981;47:2901-2903.

8 D elaire $L$, Turlure $P$, Jaccard A, L oustaud-R atti V R emenieras L, Julia A, G aillard S, B ordessoule D, $\checkmark$ idal $F$ : A cquired hemophilia caused by autoantibodies against factor VIII coagulation activity. Clinical, biological study and therapeutic indications Experience based on a study of 9 cases. A nn Med Interne (Paris) 1997;148:477-490.
9 Casas E, G arcia Puig J, Villar A , G onzales Sanz A Miranda ME, Ortiz Vazquez J: Hemorrhagic syndrome associated with a factor V III:C inhibitor in a patient with lymphoma. M ed Clin 1989;93:23-25.

10 O hthaka A, M uroi K, I zumi T, Suzuki T, H oshino M M iwa A, Sakata Y, Sakamoto S, M iura Y, Shinohara $\mathrm{N}$ : Severe bleeding in a case of factor VIII inhibitor associated with intravascular lymphomatosis. R insho Ketsueki 1993:34:194-199.

11 Stricker R, B arlogie B, Kiprov D : A cquired facto VIII inhibitor associated with chronic interferon alpha therapy. J R heumatol 1994;21:350-352.

12 B endandi $M$, Zaccaria A, Zinzani $P, V$ isani $G$ Stefanati V, Cantagalli F, Mancino A, Macchi $S$ Simoncelli $F$, Tura S: Factor VIII inhibitor prior to and during secondary acute nonlymphocytic leukemia in a patient with cured H odgkin's disease. L euk Lymphoma 1995;16:511-513.

13 L ongo G, L uppi M, Ferrara L, Torelli U, B arbieri U, Torelli G :A cquired factor V III inhibitor at the onse of prolymphocytic leukemia. Leukemia 1996;10: 1557-1558.

14 Endo $T, Y$ atomi $Y, A$ memiya $N$, M izoe $A$, L ino $M$ O zawa $\mathrm{H}, \mathrm{H}$ osogaya $\mathrm{S}, \mathrm{O}$ zaki $Y$ : A ntibody studies of factor VIII inhibitor in a case with Waldenström's macroglobulinemia. A m J Hematol 2000;63: 145-148.

15 Komiya I I to T, O gata K, Yamada T, D an K, Kuriya $S$, N omura T: D iverse hemostatic abnormalities in a patient with biclonal multiple myeloma. Rinsho Ketsueki 1990;31:62-65.
$16 \mathrm{G}$ reen $\mathrm{D}, \mathrm{R}$ ademaker $\mathrm{A}, \mathrm{B}$ riet $\mathrm{E}: \mathrm{A}$ prospective, randomized trial of prednisone and cyclophosphamide in the treatment of patients with factor VIII autoantibodies. Thromb H aemost 1993;70:753-757.

17 A usten $D$, L echner K, R izza R, R hymes I: A comparison of the Bethesda and $\mathrm{New} O \mathrm{O}$ ford methods of factor VIII antibody assay. Thromb Haemost 1982;47:72-75.

$18 \mathrm{~K}$ essler C: A $\mathrm{n}$ introduction to factor VIII inhibitors: The detection and quantitation. A m J Med 1991; 91:5A - 1S.

19 K ernoff $P$ : $R$ ationale and evolution of therapy with porcine factor VIII :C. A m J M ed 1991;91:5A -20S

20 M orrison A, Ludlam A : The use of porcine factor VIII in the treatment of patients with acquired hemophilia: The U nited $\mathrm{K}$ ingdom experience. A $\mathrm{m}$ J M ed 1991;91:5A -23S

21 Liebman H, Chediak J, Fink K, Galvez A, Shah P, Sham $R$ : A ctivated recombinant human coagulation factor VII (rFVIIa) therapy for abdominal bleeding in patients with inhibitory antibodies to factor V III A m J Hematol 2000;63:109-113.

22 Sultan $Y$, Kazatchikine M, Nydegger U, R ossi F, D ietrich $G$, A Igiman $M$ : Intravenous immunoglobulin in the treatment of spontaneously acquired factor VIII:C inhibitors. A m J M ed 1991;91:5A -35S.

23 Shaffer $L$, Phillips $M$ : Successful treatment of acquired hemophilia with oral immunosuppressive therapy. A nn Intern M ed 1997;127:206-209.

$24 \mathrm{G}$ reen $\mathrm{D}$ : Cytotoxic suppression of acquired factor VIII:C inhibitors. A m J M ed 1991;91:5A -14S. 